\title{
Acrylamide replaced by moringa extract in sugar production
}

\author{
Gustavo Henrique Gravatim COSTA ${ }^{1,2 *}$, Cristhyane Millena de FREITA ${ }^{1}$, Franciele Quintino MENDES ${ }^{1}$, \\ Juliana Pelegrini ROVIERO ${ }^{1}$, Márcia Justino Rossini MUTTON ${ }^{1}$
}

\begin{abstract}
This manuscript showed a new product that can be used in sugar and alcohol production to replace the acrylamide polymer, applied in the juice treatment. This new product is an organic extract obtained from moringa seeds, which present the flocculating protein 2S-Albumin. This biomolecule is added in the decanter together with the limed and heated juice, increasing the sedimentation speed of impurities that, if remain in the process, decrease the quality of the obtained sugar. This issue is of great importance because the acrylamide molecule has carcinogenic and neurotoxic action in humans and may be incorporated within the sugar crystal or the mud (filter-cake) used as a fertilizer. Furthermore, it should be noted that this manuscript presents the best technique to extract the S-Albumin protein from moringa seeds (using a $\mathrm{CaCl}_{2}$ solution $0.1 \mathrm{~mol} / \mathrm{L}$ ), the best dosage to apply in the sugarcane juice $(1300 \mathrm{mg} / \mathrm{L})$, and similary sugar quality achieved, compared with the process using the acrylamide polymer.
\end{abstract}

Keywords: Moringa oleifera Lamarck; crystallization; sucrose; simple liming; S-albumin.

Practical Application: The moringa extract may replaced the acrylamide in sugar production for small and large producer.

\section{Introduction}

The global sugar commodity market is currently one of the most consolidated, the sugar being sold in large commercial centers such as the United States and United Kingdom. It is estimated that in 2013/2014 approximately 180 million tons of the product had been produced, which is originates from sugarcane or the sugar beet (Food and Agriculture Organization, 2015).

In this scenario, there is growing demand for quality products and to present rigid food safety control. Thus, there is high adhesion to ISOs, such as 22,000 , by the production units to which quality is ensured. Among the established requirements, we highlight the high presence of sucrose in the crystal, the least amount of coloration possible, besides no presence of micro-organisms (salmonella and coliforms), heavy metals, pesticides and acrylamide.

Acrylamide presents restrictions due to its neurotoxic and carcinogenic actions in humans and animals (World Health Organization, 2002). It should be noted that the presence of this molecule in the sugar crystal (World Health Organization, 2011 ) is derived from the addition of an input popularly called polymer, which consists of partially hydrolyzed polyacrylamides. Its use is in the beet or cane juice treatment stage, seeking to maximize the removal of impurities, making it possible to obtain sugar with low coloration. Environmental Protection Agency (1990) shows that granulated sugar could contain $0.012 \mathrm{ppb}$ and soft sugar could contain $0.24-0.48$ ppb of acrylamide monomer.
The polymer is sold in solid form and may be anionic or cationic. When in contact with the juice, it binds to the oppositely charged molecules, forming heavy, large flakes, which settle quickly. For the processing of sugarcane, the polymer is added to the decanter along with the juice addition. It should be noted that in this production unit, after the juice is extracted and sieved it receives an addition of limewater until $\mathrm{pH}$ 7.0-8.0 and is heated to $100-105^{\circ} \mathrm{C}$, enabling the reaction of calcium ions with the phosphates present forming small coagulates called calcium phosphates. These bind to the polymer and upon sedimentation, adsorb acids, proteins, pigments, dyes, phenols and inorganic compounds, among other elements, which negatively interfere in the quality of the sugar produced (Thai et al., 2012).

In this context, alternatives are sought to replace this input, enabling safe production. Thus, we can highlight plant extracts, such as extract of moringa (Moringa oleifera Lam.), widely used as a flocculant of impurities present in water. This phenomenon occurs due to the presence of a protein in the S-albumin family present in the moringa seeds, a protein which present coagulant characteristics and do not show toxicity to humans (Freire et al., 2015). This protein is safe for handling and ingestion by humans, and is widely used, in addition to water treatment (Kansal \& Kumari, 2014), as well as in the clarification of wine. However, there is no information in the literature that relates to the effectiveness of the extract obtained from the seeds of this plant for treating sugarcane juice, as well as effects of this treatment on the produced sugar. The objective of the study was to evaluate the clarification process of cane juice using moringa seed extract, and the quality of the obtained sugar. 


\section{Materials and methods}

The experiment was installed in Sugar and Alcohol Technology Laboratory FCAV/UNESP, Jaboticabal-SP, in the season 2014/2015.

\subsection{Preparation and characterization of the extracts}

The moringa leaves and seeds were collected between May and July, 2014. The seeds were then placed in an oven at $55^{\circ} \mathrm{C}$ for 12 hours, peeled and macerated manually in a porcelain capsule.

For leaf extract preparation, cooking was carried out for 10 minutes, followed by filtration through a sieve 6 mashes (Bhatia et al., 2007).

For extraction the macerated seeds were immersed in distilled water and solutions $\mathrm{CaCl}_{2}$ at different concentrations $(0.1,0.5,1.0,1.5$ and $2.0 \mathrm{~mol} / \mathrm{L})$ in a proportion of $1 \mathrm{~g}$ seed for $100 \mathrm{~g}$ solution. The mixture was stirred for 10 minutes followed by vacuum filtration using qualitative filter paper to retain the insoluble coarse particles, as described by Okuda et al. (2001). The extracts were characterized for protein content by the Hartree (1972) method.

Due to limitations of the Hartree method, prior dialysis (MWCO $5 \mathrm{kDa}$ membrane, Sigma) of the extracts was carried out based on potassium, magnesium and calcium, against deionized water, since these salts promote precipitation of the reactants.

After determination of the concentration and the solution that promoted the highest protein extraction, we conducted characterization of this extract as to Brix, Soluble Ash, $\mathrm{pH}$ (Centro de Tecnologia Canavieira, 2009), Phenolic Compounds (Folin \& Ciocalteu, 1927) and inorganic compounds (K, Mg, Ca, $\mathrm{Na}$ and $\mathrm{Fe}$ ) (Association of Oficial Analytical Chemists, 1997).

\subsection{Dosage test}

In order to measure the optimal dosage to be used in the treatment of sugarcane juice for sugar production, a prior dosage test was conducted. The extract was applied directly in the decanter, before the addition of sugarcane juice with Brix adjusted to $16^{\circ}$, limed to $\mathrm{pH} 7.0$ and heated to boiling, where it remained at rest for 40 minutes. In this step, we tested 12 different doses $(0,5,10,50,250,1000,1300,1600$ and $2000 \mathrm{mg} / \mathrm{L})$ with 4 replications. After retention time, the clarified juice (supernatant) was syphoned off and subjected to chemical and technological characterization.

The juice variety RB855536 was used, collected from the first milling at the ethanol production plant in the region of Jaboticabal-SP.

The extracted and clarified juices obtained in the dosing test were subjected to analysis of Brix, Pol, Purity, $\mathrm{pH}$, Total Acidity, Turbidity, Total Ash (Centro de Tecnologia Canavieira, 2009), Total Phenolic Compounds (Folin \& Ciocalteu, 1927), and inorganic compounds (K, Mg, $\mathrm{Ca}, \mathrm{Na}$ and $\mathrm{Fe}$ ) (Association of Oficial Analytical Chemists, 1997). We also assessed the Sedimentation Speed of the flakes in the decanting process and the Sludge Volume formed (Centro de Tecnologia Canavieira, 2009).
It should be noted that the results were evaluated using a completely randomized experimental design with 9 treatments (doses) and 4 replications.

\subsection{Treatment of cane juice}

It was collected 6 sugarcane variety (SP80-3280, SP83-2847, CTC4, CTC7, CTC4 e IACSP95-5000) from farms of Jaboticabal-SP. The sugarcanes were in harvest point, and were cut manually and without burning of straw.

The juice was recovered by milling, sifted, standardized to Brix $16^{\circ}$ and $\mathrm{pH} 7.0$ (using calcium hydroxide $6^{\circ}$ Bé), heated until boiling point, and transferred to decanter, where was kept for 40 minutes. Before the added of juice in the decanter, it was dosed 6 flocculants:

Commercial Synthetic Polymer (CSP) - $1.5 \mathrm{mg} / \mathrm{L}$ (producer);

Commercial Organic Polymer (COP) prepared from Acácia Negra - 10 mg/L (producer);

Extract of Moringa Leaves (EML) - $800 \mathrm{mg} / \mathrm{L}$ (Costa et al., 2014);

Extract of Moringa Seeds (EMS) - $1300 \mathrm{mg} / \mathrm{L}$;

Control - no added flocculant.

After retention time, the clarified juice (supernatant) was recovered by siphoning, and the settled mud was discarded. The raw and clarified juice were subjected to analyzes of Brix, Pol, Purity, pH, Total Acidity, Turbidity, Soluble Ashes (Centro de Tecnologia Canavieira, 2009) and Total Phenolic Compounds (TPC) (Folin and Ciocalteu, 1927). The treatment process was objected of analyses of Settling Rate and Mud\% (Centro de Tecnologia Canavieira, 2009).

The experimental design used was a split-plot with 4 replications. The major treatments were represented by 6 sugarcane varieties, and the secondary treatments were represent by 5 flocculants.

\subsection{Sucrose crystallization}

After the treatment of juice, it was chose randomized 3 sugarcane varieties that were subjected to a new treatment of juice (simple lime). The clarified juice was concentrated until Brix $60^{\circ}$ (syrup) using a simple-effect evaporator. The syrup was subjected to a cooking process, conducted in a metastable zone, temperature $61 \pm 2{ }^{\circ} \mathrm{C}$. The graining was performed by adding "seeds" (small crystals of uniform size).

The crystals were recovered by centrifugation at $6300 \mathrm{~g} / 5$ minutes. It was used stem to crystal washes, in a pressure $1 \mathrm{kgf} / \mathrm{cm}^{2}$ for 2 seconds. Sugar was initially dried in a hot air drier, and then it was placed in an incubator at $35^{\circ} \mathrm{C}$ for 12 hours.

The sugar quality was determined by the analyses of Pol, $\mathrm{pH}$, Ashes, Moisture, Color, Total Phenolic Compounds (Centro de Tecnologia Canavieira, 2009), and the presence of salmonella (LFS ${ }^{\text {tm }}$ Salmonella - Madasa) total and fecal coliforms (Idexx, 2015).

The experimental design used was a split-plot with 4 replications. The major treatments were represented by 3 sugarcane varieties (SP80-3280, CTC4 and CTC14), and the secondary treatments were represent by 5 flocculants. 


\subsection{Data analysis}

The results obtained were subjected to analysis of variance using the F test, and the means were compared using the Tukey's test $(5 \%)$.

\section{Results and discussion}

\subsection{Extracion of protein}

Table 1 presents the results obtained for the protein content of the $\mathrm{CaCl}_{2}$ extract at different concentrations. These preliminary tests were used in order to establish the concentrations to be used in subsequent tests.

As noted, the use of $0.1 \mathrm{~mol} / \mathrm{L} \mathrm{CaCl}$ promoted the highest extraction of proteins present in the moringa seeds. These levels are lower than those obtained by Madrona et al. (2010), who detected values of up to $23400 \mathrm{mg} / \mathrm{L}$ of protein using $1 \mathrm{~mol} / \mathrm{L}$ of $\mathrm{KCl}$ extract. However, it should be noted that the authors did not describe prior dialysis undergone before the analysis, a fundamental step, since $\mathrm{K}$ and $\mathrm{Ca}$ ions interfere significantly in the method (Hartree, 1972).

Considering that the $0.1 \mathrm{~mol} / \mathrm{L} \mathrm{CaCl}_{2}$ extract resulted in increased protein content, this was used in subsequent tests. In this context, the next step was to characterize it. It was observed that the use of this salt promoted extract with a high Brix (16.4\%) and ash (14.7\%) content, besides an alkaline $\mathrm{pH}$ (10.3). Another salient point is that TPC were not detected. Analyzing the inorganic compounds, the presence of $0.50,0.07,0.21,2.43$ and $0.02 \mathrm{mg} / \mathrm{L}$ of $\mathrm{Na}, \mathrm{Fe}, \mathrm{K}, \mathrm{Ca}$ and $\mathrm{Mg}$, were found, respectively.

Characterization of the extract is of paramount importance, since it can change the composition of the clarified juice, resulting, for example, in calcium residues which may be precursors of incrustation in equipment such as evaporators or sugar vacuum pans (Doherty et al., 2008).

\subsection{Dosage test}

After characterization of $0.1 \mathrm{~mol} / \mathrm{L} \mathrm{CaCl}_{2}$ extract, the next step was to determine its optimal dosage as a flocculant of sugarcane juice. For this we evaluated the doses of

Table 1. Mean values of protein for the $\mathrm{CaCl}_{2}$ extract at concentration of $0.1,0.5,1.0,1.5$ and $2.0 \mathrm{~mol} / \mathrm{L}$.

\begin{tabular}{cc}
\hline Concentration & $\mathbf{C a C l}_{2}$ \\
\hline mol/L & $\mathbf{~ m g} / \mathbf{L}$ \\
\hline 0.1 & $5531 \mathrm{~A}$ \\
0.5 & $3223 \mathrm{AB}$ \\
1.0 & $2001 \mathrm{~B}$ \\
1.5 & $1879 \mathrm{~B}$ \\
2.0 & $1877 \mathrm{~B}$ \\
F Test & $8.87^{\star *}$ \\
LSD & 2310 \\
CV & 36.4 \\
\hline
\end{tabular}

Values followed by the same letter are not significantly different according to the Tukey test at $5 \%$ probability; ${ }^{* *}$ significant at $1 \%$; LSD = Low Significant Difference; $\mathrm{CV}=$ Coefficient of Variation
$0,5,10,50,250,1000,1300,1600$ and $2000 \mathrm{mg} / \mathrm{L}$. It was observed that different concentrations of the extract did not result in alterations in the juice sugars, since the Brix was $16 \%$, Pol $13.76 \%$ and Purity $86 \%$ for all treatments. These data corroborate information from Thai et al. (2012), who affirm that the juice treatment system by simple caleagem does not remove sugars from the juice. Along these lines, it can also be verified that different concentrations did not alter the $\mathrm{pH}(6.0)$ and removed Acidity (60\%) values.

Analyzing the impurity sedimentation speed values on the order of $0.44 \mathrm{~cm} / \mathrm{min}$ were observed for all treatments. These results are higher than those obtained by Costa et al. (2014), who determined speeds up $0.27 \mathrm{~cm} / \mathrm{min}$ when no polymer was used in the juice clarification process.

Figure 1 shows the values obtained for the percentage of precipitated mud in the decanter and the turbidity removed from the juice. It was found that the dose of $1300 \mathrm{mg} / \mathrm{L}$ provided the best results for both parameters analyzed. Considering the precipitated impurities, the values were similar to those obtained by Thai et al. (2012), who, using polymer in the clarification process determined from 13 to $26 \%$ mud formed in the decanter. It should be noted that the high compaction of impurities on the decanter bottom is important for the sugar mill, since afterwards, this precipitate will be filtered out to recover the juice and, the greater the volume, the greater the filter wear, making the process costly, reducing industrial earnings.

Evaluating the turbidity removed, it was observed that the results were superior to those determined by Andrzejewski et al. (2013), who studied different juice clarification systems and found $76 \%$ removal of turbidity from the clarified sugarcane juice when using the simple liming system with the addition of $10 \mathrm{ppm}$ of polymer.

Comparing the $\mathrm{K}, \mathrm{Na}, \mathrm{Mg}$, $\mathrm{Ca}$ and $\mathrm{Fe}$ concentrations in the clarified juice with different doses of $\mathrm{CaCl}_{2}$ moringa seed extract (Table 2) in relation to the original juice, it was observed that there was no significant reductions in $\mathrm{K}, \mathrm{Na}, \mathrm{Mg}$ and Fe. However, a slight increase $\mathrm{Ca}$ can be observed. The residual calcium can be the result of the liming process, since Andrzejewski et al. (2013) also detected the presence of $8 \mathrm{mg} / \mathrm{L}$ of this element in the

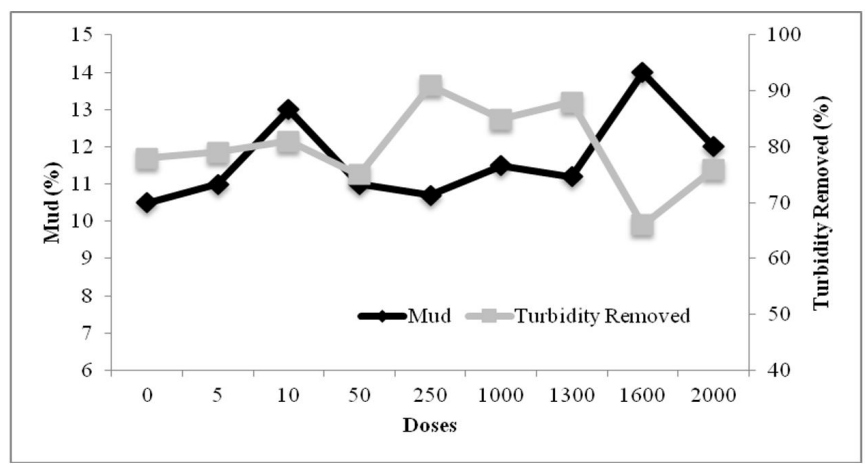

Figure 1. Mud \% in the decanter and Turbidity removed from clarified juice, using different doses of $0.1 \mathrm{~mol} / \mathrm{L} \mathrm{CaCl}_{2}$ moringa extract as sedimentation agent. 
Table 2. Potassium (K), Sodium (Na), Magnesium (Mg), Calcium (Ca), Iron (Fe), Ash removed and TPC (Total Phenolic Compounds) removed from clarified juice with different moringa extract doses.

\begin{tabular}{|c|c|c|c|c|c|c|c|}
\hline \multirow{2}{*}{$\begin{array}{c}\text { Doses } \\
(\mathrm{mg} / \mathrm{L})\end{array}$} & $\mathbf{K}$ & $\mathrm{Na}$ & $\mathrm{Mg}$ & $\mathrm{Ca}$ & $\mathrm{Fe}$ & Ashes Removed & TPC Removed \\
\hline & \multicolumn{5}{|c|}{$\mathrm{mg} / \mathrm{L}$} & \multicolumn{2}{|c|}{$\%$} \\
\hline Raw Juice & 0.81 & 0.61 & 0.25 & 0.37 & 3.91 & 0.63 & $510^{¥}$ \\
\hline $\mathbf{0}$ & 0.04 & 0.12 & $0.21 \mathrm{AB}$ & 0.46 & 0.40 & $27 \mathrm{~A}$ & $51 \mathrm{ABC}$ \\
\hline 5 & 0.03 & 0.11 & $0.20 \mathrm{AB}$ & 0.42 & 0.30 & $27 \mathrm{~A}$ & $53 \mathrm{ABC}$ \\
\hline 10 & 0.03 & 0.10 & $0.20 \mathrm{AB}$ & 0.41 & 0.28 & $27 \mathrm{~A}$ & $54 \mathrm{AB}$ \\
\hline 50 & 0.04 & 0.11 & $0.23 \mathrm{~A}$ & 0.48 & 0.41 & $26 \mathrm{AB}$ & $52 \mathrm{ABC}$ \\
\hline 250 & 0.03 & 0.10 & $0.16 \mathrm{~B}$ & 0.43 & 0.29 & $22 \mathrm{AB}$ & $55 \mathrm{~A}$ \\
\hline 1000 & 0.03 & 0.10 & $0.21 \mathrm{AB}$ & 0.48 & 0.43 & $22 \mathrm{AB}$ & $50 \mathrm{ABC}$ \\
\hline 1300 & 0.03 & 0.11 & $0.20 \mathrm{AB}$ & 0.47 & 0.17 & $23 \mathrm{AB}$ & $52 \mathrm{BC}$ \\
\hline 1600 & 0.03 & 0.10 & $0.21 \mathrm{AB}$ & 0.50 & 0.26 & $21 \mathrm{AB}$ & $50 \mathrm{ABC}$ \\
\hline 2000 & 0.03 & 0.12 & $0.21 \mathrm{AB}$ & 0.50 & 0.30 & $21 \mathrm{~B}$ & $53 \mathrm{ABC}$ \\
\hline F Test & $1.10 \mathrm{~ns}$ & $1.68 \mathrm{~ns}$ & $1.92^{*}$ & $2.22 \mathrm{~ns}$ & $0.93 \mathrm{~ns}$ & $3.79^{* *}$ & $3.47^{\star \star}$ \\
\hline LSD & 0.02 & 0.03 & 0.06 & 0.10 & 0.41 & 5.74 & 7.44 \\
\hline $\mathrm{CV}$ & 24.03 & 9.81 & 12.96 & 9.56 & 54.65 & 9.52 & 5.80 \\
\hline
\end{tabular}

Values followed by the same letter are not significantly different according to the Tukey test at $5 \%$ probability; ns $=$ not significant; ${ }^{*}$ significant at $5 \%$; ${ }^{* *}$ significant at $1 \%$; $¥=$ mg/L; LSD = Low Significant Difference; CV = Coefficient of Variation.

Table 3. Mean values obtained to Brix, Pol, Soluble Ashes, Total Acidity, Total Phosphates, Total Phenolic Compounds (TPC), Color and Turbidity of raw juice extract from the sugarcane varieties SP80-3280, CTC4, CTC7, IACSP95-5000 and CTC14. Jaboticabal-SP. Season 2014/2015.

\begin{tabular}{|c|c|c|c|c|c|c|c|c|c|}
\hline \multirow[t]{2}{*}{ Varieties } & Brix & Pol & Purity & $\begin{array}{c}\text { Soluble } \\
\text { Ashes }\end{array}$ & \multirow{2}{*}{$\frac{\text { Total Acidity }}{\mathrm{g} / \mathrm{L}}$} & Total Phosphates & TPC & \multirow{2}{*}{$\begin{array}{c}\text { Color } \\
\text { U.I. } \\
\end{array}$} & \multirow{2}{*}{$\frac{\text { Turbidity }}{\text { NTU }}$} \\
\hline & \multicolumn{4}{|c|}{$\%$} & & \multicolumn{2}{|l|}{$\mathrm{mg} / \mathrm{L}$} & & \\
\hline SP80-3280 & 24.7 & 21.79 & 88.2 & 0.49 & 0.79 & 356 & 625 & 33.633 & 508 \\
\hline CTC4 & 24.0 & 21.79 & 90.8 & 0.49 & 0.79 & 445 & 492 & 35.729 & 508 \\
\hline CTC7 & 25.1 & 21.82 & 86.9 & 0.98 & 1.30 & 561 & 701 & 26.647 & 892 \\
\hline SP95-5000 & 22.5 & 18.87 & 83.9 & 0.90 & 1.21 & 282 & 437 & 37.525 & 1046 \\
\hline SP83-2847 & 22.7 & 18.24 & 80.4 & 1.06 & 0.79 & 1151 & 433 & 11.776 & 1128 \\
\hline CTC14 & 19.7 & 19.11 & 97.0 & 0.78 & 1.36 & 525 & 448 & 11.776 & 969 \\
\hline
\end{tabular}

U.I. = Unity ICUMSA; NTU = Nephelometric Turbidity Units.

clarified juice, and this amount represented an increase of $100 \%$ over the original juice.

Considering the dosages it can be seen that only the concentrations of 250, 1000 and $1300 \mathrm{mg} / \mathrm{L}$ were effective for the removal of $\mathrm{Mg}$, and there was no significant effect on the other parameters.

It should also be noted that there was a juice ash reduction of approximately $24 \%$ in relation to the original and $50 \%$ reduction in the phenol content (Table 2). This fact is interesting because some authors, (Honig, 1969; Albuquerque, 2011), state that the simple liming process does not remove phenols from the juice.

In this context, the $1300 \mathrm{mg} / \mathrm{L}$ dosage was considered the most suitable to be used in subsequent tests.

\subsection{Juice treatment}

After determined the ideal dose of EMS, the next step was made the juice treatment of 6 sugarcane varieties, comparing with commercial inputs. In this way, primarily it was characterized the raw juice (Table 3 ).
Whereas in the maturing stage the sugarcane shows Pol and Purity higher than 14 and $85 \%$, respectively, and Total Acidity lower than $0.80 \mathrm{~g} / \mathrm{L} \mathrm{H}_{2} \mathrm{SO}_{4}$ (Ripoli \& Ripoli, 2009), we observed that all varieties were apt to be processed. However, it should be highlight that SP83-2847, although showed Pol 18\%, presented a lot of non-sucrose compounds in constitution, which decreased the juice purity. This fact is confirmed by values obtained to Soluble Ashes that was higher than 1\%. Similar behavior was verified to varieties CTC7, IACSP95-5000 and CTC14, which we observed Total Acidity higher than $1.0 \mathrm{~g} / \mathrm{L}$. However, the sugarcane maturity is not defined for one parameter, because other factors may be interfere, as plagues, weather, diseases, and others.

The raw juice was standardized and subjected to a clarification process by simple liming, using different flocculants.

In Figure 2, there are showed the values obtained for settling rate and mud\%. Considering the varieties, we observed that SP83-2847 did not promoted sedimentation of impurities, independently of flocculent used, fact verified by velocity next $0 \mathrm{~cm} / \mathrm{min}$, and mud\% next $100 \%$. Probably the high phosphates concentration in the raw juice affected negatively the process 


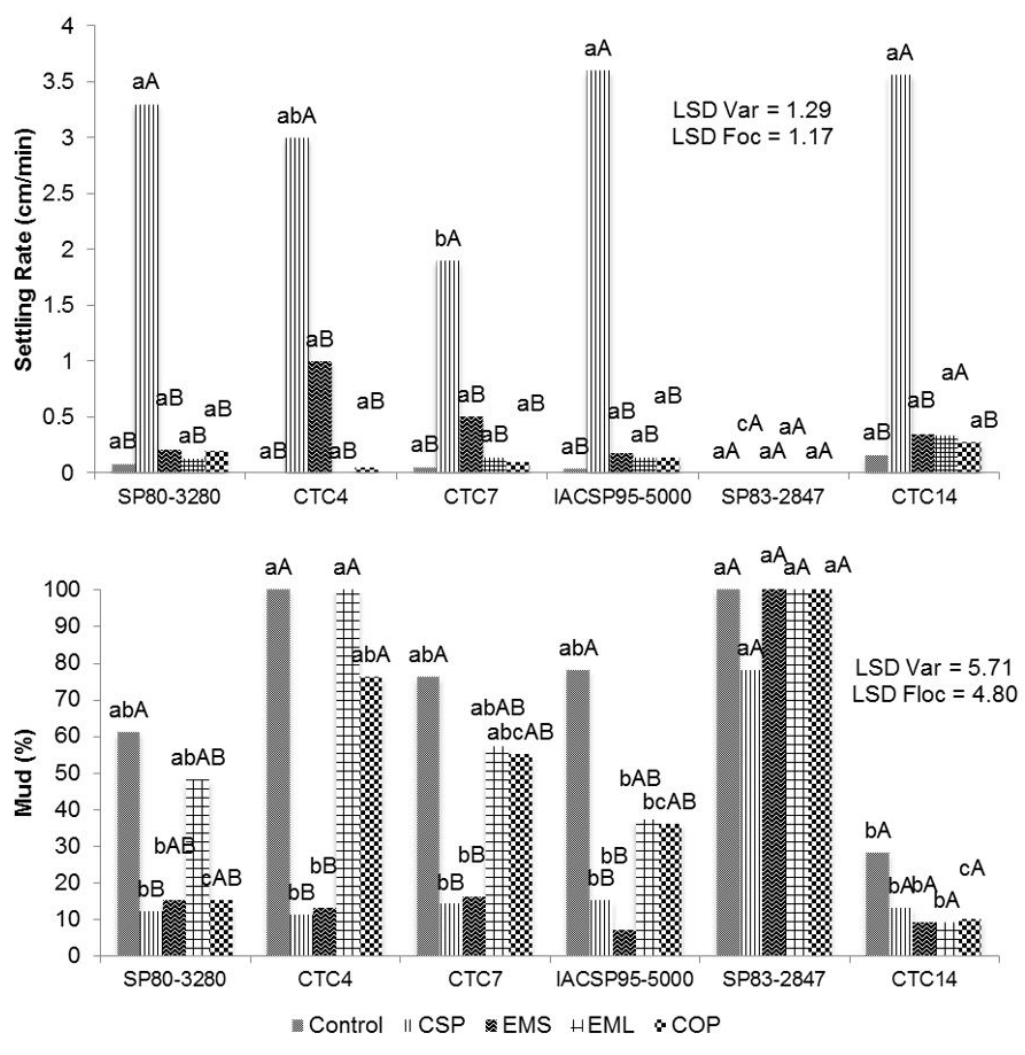

Figure 2. Interaction between sugarcane and flocculants for the parameters: (A) settling rate; (B) Mud\%. Lowercase letters compare varieties, and uppercase letters compare flocculants. LSD = Low Significant Difference. Jaboticabal-SP. Season 2014/2015.

because higher levels of this molecule promote voluminous mud (Honig, 1969).

Evaluating the effect of flocculant in settling rate, it was verified that CSP showed higher values than others. The EMS presented efficiency only for variety CTC4. These results are similar that determined by Costa et al. (2014), who evaluated settling rate of $2 \mathrm{~cm} / \mathrm{min}$ for synthetic polymer Flomex 9076, and $0.20 \mathrm{~cm} / \mathrm{min}$ for treatments that was used extract of moringa leaves and control.

Analyzing the mud\%, we observed that the CSP and EMS promoted low values than others. These results were lower than that obtained by Costa et al. (2014), who verified mud in $25 \%$ of decanter, when they processed the varieties RB855156 and SP83-2847. It should be highlight that the process of SP83-2847 did not result in mud in the decanter bottom (similar behavior that obtained by settling rate).

It was not observed sugar remove (Brix, Pol and Purity) when used these 5 flocculants, and all treatments promoted $60 \%$ of acidity reduction. These results were similar that obtained in dosing test.

In Table 4 there are showed the values obtained for Total Phosphates, Soluble Ashes and Turbidity Removed. The phosphates removed were $150-200 \mathrm{mg} / \mathrm{L}$ in relation of raw juice. The remove of these compounds was expected, because the phosphate react with calcium, becomes insoluble and precipitates, adsorbing
Table 4. Mean values obtained for Phosphates Removed, Ashes Removed and Turbidity Removed of clarified juice using 5 flocculants and 6 sugarcane varieties. Jaboticabal-SP. Season 2014/2015.

\begin{tabular}{lccc}
\hline & $\begin{array}{c}\text { Phosphates } \\
\text { Removed }\end{array}$ & Ashes Removed & $\begin{array}{c}\text { Turbidity } \\
\text { Removed }\end{array}$ \\
\hline Varieties (V) & & $\%$ & \\
SP80-3280 & $15 \mathrm{D}$ & $35 \mathrm{~A}$ & $59 \mathrm{AB}$ \\
CTC4 & $36 \mathrm{C}$ & $31 \mathrm{AB}$ & $59 \mathrm{AB}$ \\
CTC7 & $36 \mathrm{C}$ & $24 \mathrm{ABC}$ & $66 \mathrm{~A}$ \\
IACSP95-5000 & $69 \mathrm{~B}$ & $16 \mathrm{CD}$ & $71 \mathrm{~A}$ \\
SP83-2847 & $83 \mathrm{~A}$ & $19 \mathrm{BCD}$ & $30 \mathrm{~B}$ \\
CTC14 & $33 \mathrm{C}$ & $9 \mathrm{D}$ & $57 \mathrm{AB}$ \\
F Test & $202.92^{\star *}$ & $9.92^{\star *}$ & $3.36^{*}$ \\
DMS & 8.00 & 14.04 & 35.25 \\
CV & 17.39 & 61.20 & 61.15 \\
Flocculants (F) & & & \\
Control & 43 & 23 & $41 \mathrm{C}$ \\
CSP & 48 & 22 & $77 \mathrm{~A}$ \\
EMS & 46 & 20 & $57 \mathrm{~B}$ \\
EML & 45 & 21 & $57 \mathrm{~B}$ \\
COP & 45 & 26 & $52 \mathrm{~B}$ \\
F Test & $1.20 \mathrm{~ns}$ & $1.63 \mathrm{~ns}$ & $20.39^{* *}$ \\
CV & 16.54 & 33.65 & 25.20 \\
LSD & 6.12 & 6.21 & 11.69 \\
Inter. VxF & $1.90 \mathrm{~ns}$ & $0.94 \mathrm{~ns}$ & $0.62 \mathrm{~ns}$ \\
\hline V & & &
\end{tabular}

Values followed by the same letter are not significantly different according to the Tukey test at $5 \%$ probability; ns = not significant; ${ }^{* *}$ significant at $1 \%$ LSD $=$ Low Significant Difference; $\mathrm{CV}=$ Coefficient of Variation. 
and lugging organic and inorganic compounds for the bottom of decanter (Thai et al., 2012).

Analyzing the soluble ashes in the clarified juice, it was verified similar behavior that observed in raw juice, because the varieties SP80-3280 and CTC4 showed the lower values than others. Costa et al. (2014) determined that the soluble ashes variety according raw material, and may increase in clarified juice due the lime. It admits that the higher volume of calcium added, higher the possibility of increases the ashes in clarified juice. It happens especially in raw material rich in aconitic acid, because this molecule reacts with calcium too (Honig, 1969). These ashes may results in incrustation in boilers (Doherty, 2011) and may be included in sugar crystals (Albuquerque, 2011).

The flocculants did not presented effects of phosphates total and soluble ashes in clarified juice. In this context, it is possible infer that the phosphates and ions present in the juice, do not react with flocculants, however may be adsorbed for flocks.

Evaluating the turbidity of clarified juice from different varieties, we observed that the clarification of SP83-2847 resulted in lower values than others. This happened because there was not sedimentation, promoting suspended particles, which are quantified by turbidimeter. In this way, the results of turbidity remove was convergent those obtained to settling rate and mud\%. Considering the effect of flocculants in this parameter, it was verified that the use of CSP promoted juice lighter than the others. The organic flocculants (EMS, EML and COP) and control resulted in $20 \%$ and $36 \%$ less turbidity remove, respectively, than CSP.
In Figure 3 is showed the values obtained for TPC. In general, we observed that there was significant reduction of those biomolecules, especially for varieties SP80-3280, CTC4 and CTC7 that presented higher values of phenol in raw juice. These results are similar that obtained by Costa et al. (2014), which found the remove of this biomolecules by simple liming. However, some authors (Honig, 1969; Albuquerque, 2011) affirm that this process do not remove phenol of raw juice. This behavior was observed too when processed the varieties IACSP95-5000, SP83-2847 and CTC14. Probability the remove of TPC is related with raw material used, that present different classes of phenolics. Duarte-Almeida et al. (2011) studying the phenolic compounds of 3 sugarcane varieties, observed presence of cumaric acid in proportion of $1.41,0.50$ and $1.21 \mathrm{mg} / \mathrm{L}$, clorogenic acid in proportion of $1.52,1.60$ and $1.11 \mathrm{mg} / \mathrm{L}$, and aspergin in proportion of $0.56,0.26$ and $0.60 \mathrm{mg} / \mathrm{L}$ for the varieties SP80-1842, SP81-3250 and RB855486, respectively.

Characterizing the effect of flocculants in TPC, we observed that the CSP and EMS resulted in lower values than others when processed variety CTC7. In general, the values was similar that determined by Costa et al. (2014), that quantified 400-600 $\mathrm{mg} / \mathrm{L}$ of these biomolecules in the clarified juice of varieties RB867515 and SP83-2847. It should be noted that these compounds are undesirable in sugar technology because it reacts with oxygen from the air and iron ions, resulting in the formation of colored compounds.

Considering the color of clarified juice, it was observed that the juice treatment by simple liming significantly reduced

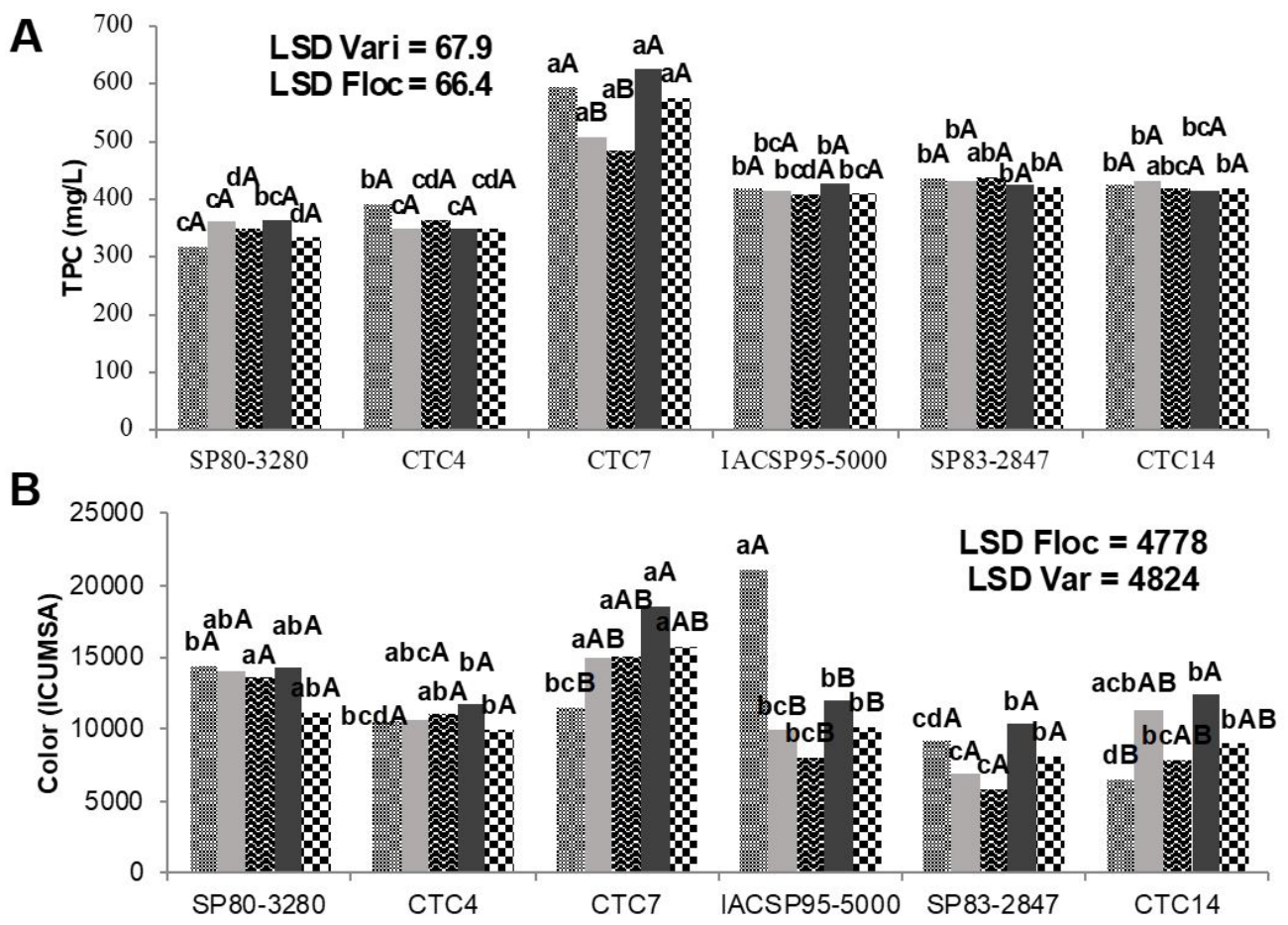

Figure 3. Interaction between sugarcane and flocculants for the parameters: (A) Total Phenolic Compounds (TPC); (B) Color. Lowercase letters compare varieties, and uppercase letters compare flocculants. LSD = Low Significant Difference. Jaboticabal-SP. Season $2014 / 2015$. 
the juice color for all varieties used. It should be noted that the juice color is directly related to particulate matter, as land, and ionic and molecular elements such as pigments, dyes, phenolic compounds, proteins, amino acids, among others, that are eliminated by this treatment. Moreover, it is noteworthy that, in general, processing CTC7 variety resulted in the largest color indexes clarified juice in relation to the other. This may be associated with increased presence of CFT this raw material, since these have a direct relationship with the juice color as described previously. The values obtained are similar to those determined by Costa et al. (2014), who reported differences in color of the clarified juice of different varieties, which are within the range of 8000 to 14000 UI. Andrzejewski et al. (2013) determined clarified juice of $11000 \mathrm{UI}$ order.

Comparing the flocculants, it was observed that the use of non-flocculation resulted in higher color when processed broth to IACSP95-5000 range. In addition, all treatments showed similar behavior.

\subsection{Sugar quality}

After the juice treatment three varieties of sugarcane were selected (SP80-3280, CTC4 and CTC14), which were processed, and the extracted juice subjected to clarification, evaporation, cooking, crystallization and centrifugation to separate the sugar crystals and molasses. The sugar was dried and characterized as to Ash, Color, TPC, Moisture, $\mathrm{pH}$ (Figure 4) and Pol.

Assessing the ash content of the sugar, the processing of CTC14 cane resulted in higher sugar ash content. In contrast, processing of SP80-3280 variety resulted in sugar with less ash. This behavior is a result of technological constitution of the raw material itself, since the CTC14 already had $0.50 \%$ more ash in the extracted juice in relation to the other varieties. Wojtczak et al. $(2013,2014)$ and Bettani et al. (2014) studying ash samples from different raw sugars determined values between 0.2 and $0.4 \%$, results similar to those obtained for the SP80-3280 and CTC4 varieties.
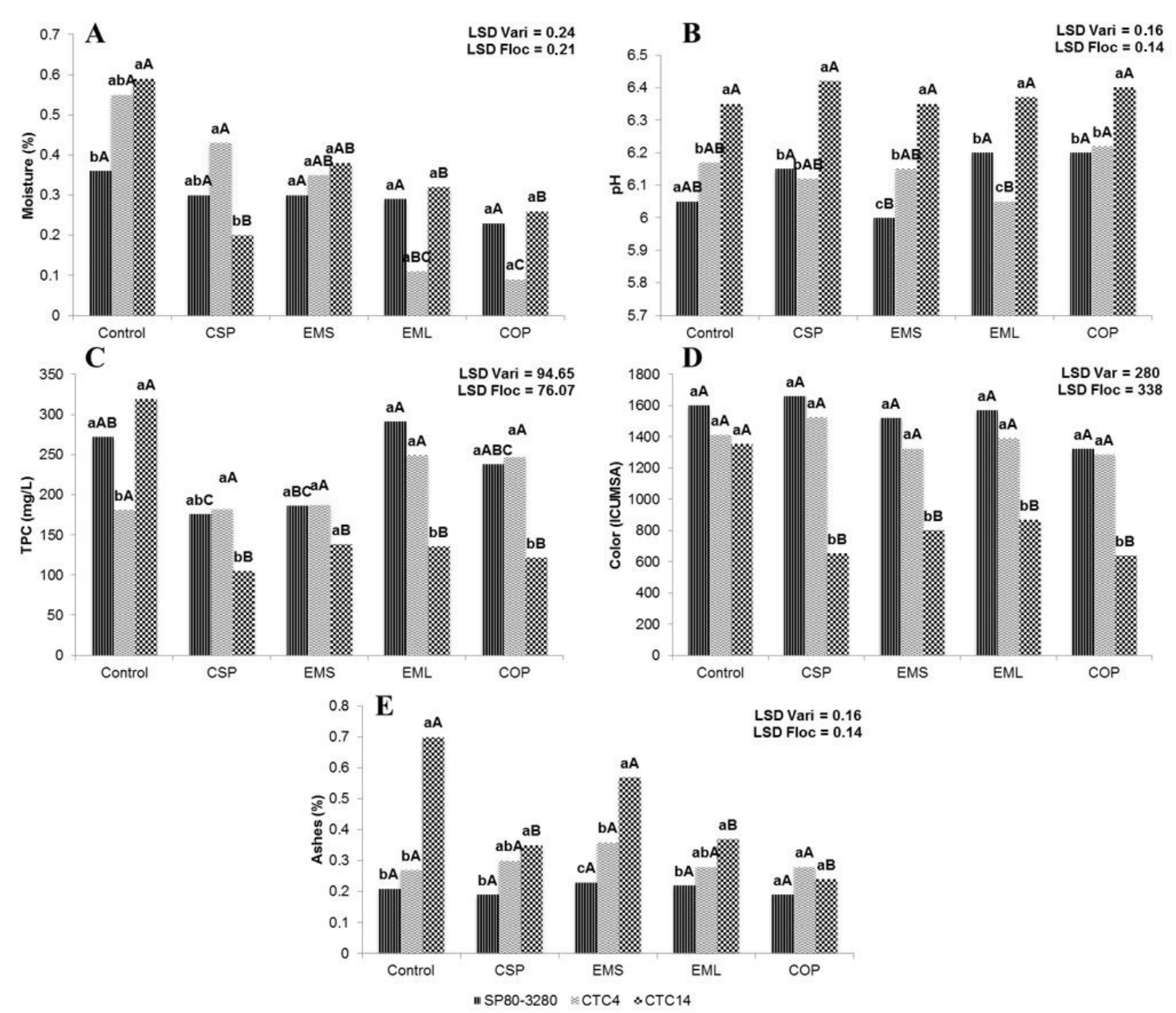

Figure 4. Interaction between sugarcane and flocculants, to sugar producer, for the parameters: (A) Moisture; (B) pH; (C) Total Phenolic Compounds (TPC); (D) Color; (E) Ashes. Lowercase letters compare varieties, and uppercase letters compare flocculants. LSD = Low Significant Difference. Jaboticabal-SP. Season 2014/2015. 
Considering the effect of flocculants on the sugar ash, an effect was found only for the CTC14 variety, and the CSP, MLE and $\mathrm{COP}$ resulted in lower values in relation to other parameters. Costa et al. (2015) found the same behavior when using CSP and MLE as clarifying agents of juice from variety RB867515 processing, and the resulting sugar presented lower ash content. These elements are directly detrimental to the refining industries since they reduce the performance and efficiency of the factory, adversely affecting product quality (Albuquerque, 2011).

The color of sugars resulting from CTC14 variety processing was less compared to the others. This behavior had been observed for the extracted and clarified juices. Thus, it can be inferred that the color of the sugar is directly related to the quality of the feedstock processed. This fact has previously been confirmed by Costa et al. (2014), who determined that the use of variety RB92579 as a raw material results in more color of the sugar compared to the use of RB86-7515.

In addition to the varieties, it was observed that the flocculants also significantly influence the color of the final product. In this test, it was observed that the use of flocculants (CSP, MSE, MLE and $\mathrm{COP}$ ) promoted less color in the product in relation to the control treatment. This behavior is interesting because it shows, along with the results for clarified juice, that the sedimentation agents promote greater removal of colored products such as pigments, dyes, etc. The values obtained in this test were lower than those determined by Wojtczak et al. (2014), who evaluated raw sugar samples from Europe and found average values of 2300 I.U. Bettani et al. (2014), comparing the quality of demerara sugar sold in Brazil, observed values between 343 and 2461 I.U.

The color of the sugar results mainly from a film of honey around the crystal that was not removed by centrifugation, to the connection of honey to surface or the entire crystal by adsorption forces (dextran, caramels, etc.), and the occlusion of mother-liquor within the crystal due to fast crystallization speed (Albuquerque, 2011). However, the amount of phenolic compounds may also directly affect the results (Simioni et al., 2006), as well as the presence of amino acids which can trigger the Maillard reaction, and heating at temperatures above $120^{\circ} \mathrm{C}$, which promotes sucrose caramelization (Sengar \& Sharma, 2014). It should also be noted that this parameter is fundamental in the classification of sugar, since this will influence the production of products that require less color, such as soft drinks, alcohol, drugs, ice cream and refreshing candies, among others (Oliveira et al., 2007).

Evaluating the Pol of the sugars, we observed that there was no difference among the treatments. In general, the values were close to $97 \%$, rates similar to those obtained by Bettani et al. (2014), Costa et al. (2014) and Wojtczak et al. (2014), who determined apparent sucrose in the same concentration range. It is assumed that sugar with a Pol less than $99.7^{\circ} \mathrm{Z}$ are intended for processing in industries such as refineries, food and pharmaceutical, among others. In this case the product is classified as VHP or Demerara (Oliveira et al., 2007).

The moisture of the sugars was directly influenced by the use of flocculants in the juice treatments, the use of these inputs resulting in lower water content within the sugar crystal, when processing the CTC4 and CTC14 varieties. It should be noted that the moisture is related to the film of honey wrapped around the crystal not being separated in the centrifuge, as well as poor centrifugation (Albuquerque, 2011). These results were lower than those determined by Costa et al. (2014), who on evaluating moisture in VHP sugars produced from two sugarcane varieties found values up to $0.5 \%$. Comparing the extracts, it was found that the use of MLE and COP promoted lower humidities than the others. Costa et al. (2014) studied the action of MLE in the juice treatment on the quality of sugar and also found that the extract results in lower sugar moisture.

Another point to note is that the presence of water in the crystals can result, in addition to sugar clumping, in the development of pathogenic microorganisms, such as salmonella and coliforms (total and fecal). In this regard, the presence of these bacteria in the sugar was not observed, unlike Wojtczak et al. (2012), who detected yeasts and bacteria in European commercial sugars. However, it should be noted that these microorganisms arrive in the industry together with the raw material. Such microorganisms may even be the result of uncontrolled hygiene during final sugar finishing operations, such as use of low quality centrifuge wash water, human manipulation, sugar powder and dirty bags, among others.

Comparing the TPC of sugar produced from different sugarcane varieties, using 5 different flocculants in the juice treatment, it was found that the use of CSP and MSE resulted in lower levels compared to the others. These results are different from those observed by Costa et al. (2014), who found no differences in the TPC content of sugars produced from juice clarified with flocculants. However, the values obtained in this present study are similar to those determined by those authors, which were $260 \mathrm{mg} / \mathrm{kg}$.

Furthermore, it is worth noting that the presence of TPC can promote color formation in the sugar crystal, promoting deterioration of the product during storage time (Simioni et al., 2006). Along these lines, the use of CSP and MSE as sugarcane juice sedimentation agents can result in a product with longer shelf life.

Considering the $\mathrm{pH}$ of the sugars produced, it was observed that the processing of the CTC14 variety, and use of the COP flocculant resulted in increased sugar $\mathrm{pH}$. It must be considered that the sugar production process is completely carried out with the clarified juice and syrup at $\mathrm{pH}$ 7.0-8.0, as it prevents the alkaline or acid degradation of sucrose and provides crystals in the a $\mathrm{pH}$ range close to neutrality. These values are similar to those determined by Bettani et al. (2014) and Costa et al. (2014) who observed $\mathrm{pH}$ ranging from 6.0 to 6.7 for different sugar samples.

\section{Conclusion}

The $0.1 \mathrm{~mol} / \mathrm{L} \mathrm{CaCl}_{2}$ solution is the most effective for extracting the highest amount of moringa seed protein, the dose of $1300 \mathrm{mg} / \mathrm{L}$ ideal for use in sedimentation.

The use of flocculants for the treatment of the juice results in less sugar color and turbidity compared to the control treatment. 
There are no differences in the quality of sugar when comparing moringa extracts and the synthetic polyelectrolyte. The sugarcane variety has direct relation on these parameters.

\section{Acknowledgements}

The authors a gratefully acknowledge CAPES (Brazilian research supporting foundation) for granting the research scholarship.

\section{References}

Albuquerque, F. M. (2011). Processo de fabricação de açúcar (2. ed.). Recife: UFPE.

Andrzejewski, B., Eggleston, G., Lingle, S., \& Powell, R. (2013). Development of a sweet sorghum juice clarification method in the manufacture of industrial feedstocks for value-added fermentation products. Industrial Crops and Products, 44, 77-87. http://dx.doi.org/10.1016/j. indcrop.2012.10.028.

Association of Oficial Analytical Chemists - AOAC. (1997). Official methods of analysis (18th ed.). Gaithersburg: AOAC.

Bettani, S. R., Lago, C. E., Faria, D. A. M., Borges, M. T. M. R., \& VerrumaBernardi, R. (2014). Avaliação físico-química e sensorial de açúcares orgânicos e convencionais. Revista Brasileira de Produtos Agroindustriais, 16(2), 155-162. http://dx.doi.org/10.15871/1517-8595/rbpa.v16n2p155-162.

Bhatia, S., Othman, Z., \& Ahmad, A. L. (2007). Pretreatment of palm oil mill effluent (POME) using Moringa oleifera seeds as natural coagulant. Journal of Hazardous Materials, 145(1-2), 120-126. http://dx.doi. org/10.1016/j.jhazmat.2006.11.003. PMid:17141409.

Centro de Tecnologia Canavieira - CTC. (2009). Manual de métodos de análises para açúcar. Piracicaba: Centro de Tecnologia Canavieira.

Costa, G. H. G., Masson, I. S., Freita, L. A., Roviero, J. P., \& Mutton, M. J. R. (2014). Use of Moringa oleífera Lamarck leaf extract as sugarcane juice clarifier: effects on clarifed juice and sugar. Food Science and Technology, 34(1), 204-209. http://dx.doi.org/10.1590/S0101-20612014000100029.

Costa, G. H. G., Masson, I. S., Freita, L. A., Roviero, J. P., \& Mutton, M. J. R. (2015). Reflexos da clarificação do caldo de cana com moringa sobre compostos inorgânicos do açúcar VHP. Revista Brasileira de Engenharia Agrícola e Ambiental, 19(2), 154-159. http://dx.doi.org/10.1590/18071929/agriambi.v19n2p154-159.

Doherty, W. O. S., Simpson, R. F., \& Rackemann, D. W. (2008). Enhanced performance of caustic soda used for the removal of scale in sugar mill evaporators. International Sugar Journal, 110, 344-349.

Doherty, W. O. S. (2011). Improved sugar cane juice clarification by understanding calcium oxide-phosphate-sucrose systems. Journal of Agricultural and Food Chemistry, 59(5), 1829-1836. http://dx.doi. org/10.1021/jf1043212. PMid:21322558.

Duarte-Almeida, J. M., Salatino, A., Genovese, M. I., \& Lajolo, F. M. (2011). Phenolic composition and antioxidant activity of culms and sugarcane (Saccharum officinarum L.) products. Food Chemistry, 125(2), 660-664. http://dx.doi.org/10.1016/j.foodchem.2010.09.059.

Environmental Protection Agency - EPA. (1990). Assesment of health risks from exposure to acrylamide. Washington: EPA.

Folin, O., \& Ciocalteu, V. (1927). On tyrosine and tryptophane determinations in proteins. The Journal of Biological Chemistry, 73(2), 627-650.

Food and Agriculture Organization - FAO. (2015). Sugar. Rome: FAO. Retrieved from http://www.fao.org/fileadmin/templates/est/COMM_MARKETS_ MONITORING/Sugar/Documents/Su_summary_FOnov13_2_pdf

Freire, J. E., Vasconcelos, I. M., Moreno, F. B., Batista, A. B., Lobo, M. D., Pereira, M. L., Lima, J. P., Almeida, R. V., Sousa, A. J., Monteiro-Moreira,
A. C., Oliveira, J. T., \& Grangeiro, T. B. (2015). Mo-CBP3, an antifungal chitin-binding protein from Moringa oleifera seeds, is a member of the 2S albumin family. PLoS One, 10(3), 1-24. http://dx.doi.org/10.1371/ journal.pone.0119871. PMid:25789746.

Hartree, E. F. (1972). Determination of protein: a modification of the Lowrey method that gives a linear photometric response. Analytical Biochemistry, 48(2), 422-427. http://dx.doi.org/10.1016/0003-2697(72)90094-2. PMid:4115981.

Honig, P. (1969). Princípios de tecnologia azucareira (Vol. 1). Mexico: Companhia Editorial Continental.

Idexx. (2015). Colilert ${ }^{\circledR}$ : a rapid method for coliforms determination. Maine: Idexx. Retrieved from https://www.idexx.com/resource-library/water/ colilert-procedure-en.pdf

Kansal, S. K., \& Kumari, A. (2014). Potential of M. oleifera for the treatment of water and wastewater. Chemical Reviews, 114(9), 4993-5010. http:// dx.doi.org/10.1021/cr400093w. PMid:24495201.

Madrona, G. S., Serpelloni, G. B., Vieira, A. M. S., Nishi, L., Cardoso, K. C., \& Bergamasco, R. (2010). Study of the effect of saline solution on the extraction of the Moringa oleifera seed's active component for water treatment. Water, Air, and Soil Pollution, 211(1), 409-415. http://dx.doi. org/10.1007/s11270-009-0309-0.

Okuda, T., Baes, A. U., Nishijima, W., \& Okada, M. (2001). Coagulation mechanism of salt solution extracted active component in Moringa oleifera seeds. Water Research, 35(3), 830-834. http://dx.doi.org/10.1016/ S0043-1354(00)00296-7. PMid:11228982.

Oliveira, D. T., Esquiaveto, M. M. M., \& Silva, J. F. Jr. (2007). Impacto dos itens da especificação do açúcar na indústria alimentícia. Food Science and Technology, 27(Suppl), 99-102. http://dx.doi.org/10.1590/S010120612007000500018.

Ripoli, T. C., \& Ripoli, M. L. C. (2009). Biomassa de cana-de-açúcar: colheita, energia e ambiente (2. ed.). Piracicaba: Edição dos Autores.

Sengar, G., \& Sharma, H. K. (2014). Food caramels: a review. Journal of Food Science and Technology, 51(9), 1686-1696. http://dx.doi.org/10.1007/ s13197-012-0633-z. PMid:25190825.

Simioni, K. R., Silva, L. F. L. F., Barbosa, V., Ré, F. E., Bernadino, C. P., Lopes, M. L., \& Amorim, H. V. (2006). Efeito da variedade e época de colheita no teor de fenóis totais em cana-de-açúcar. STAB Açúcar, Álcool e Subprodutos, 24, 36-39.

Thai, C. C. D., Bakir, H., \& Doherty, W. O. S. (2012). Insights to the clarification of sugar cane juice expressed from sugar cane stalk and trash. Journal of Agricultural and Food Chemistry, 60(11), 2916-2923. http://dx.doi.org/10.1021/jf204998b. PMid:22364593.

Wojtczak, M., Antczak, A., \& Lisik, K. (2013). Contamination of commercial cane sugars by some organic acids and some inorganic anions. Food Chemistry, 136(1), 193-198. http://dx.doi.org/10.1016/j. foodchem.2012.07.036. PMid:23017412.

Wojtczak, M., Biernasiak, J., \& Papiewska, A. (2012). Evaluation of microbiological purity of raw and refined white cane sugar. Food Control, 25(1), 136-139. http://dx.doi.org/10.1016/j.foodcont.2011.10.031.

Wojtczak, M., Antczak, A., \& Lisik, K. (2014). Starch content in various types of cane sugars as a criterion of quality and authenticity. International Journal of Food Properties, 17(3), 610-617. http://dx.doi.org/10.1080/ 10942912.2012.654565.

World Health Organization - WHO. (2002). Consecuencias sanitarias de las presencia de acrilamida en los alimentos. Genebra: WHO.

World Health Organization - WHO. (2011). Acrylamide in drinking-water. Genebra: WHO. 